Editorial

\title{
Special Issue on "Thin Film Processes"
}

\author{
Hyun Wook Jung \\ Department of Chemical and Biological Engineering, Korea University, Seoul 02841, Korea; \\ hwjung@grtrkr.korea.ac.kr
}

Received: 8 May 2020; Accepted: 8 May 2020; Published: 11 May 2020

Thin film processes are significantly incorporated in manufacturing display panels, secondary batteries, fuel/solar cells, catalytic films, membranes, adhesives, and other commodity films. This Special Issue on "Thin Film Processes". listed recent progresses on thin film processes, covering theoretical considerations, experimental observations, and computational techniques.

Articles in this issue consider comprehensive studies on thin film processes and related materials. Moon et al. [1] proposed the novel fabrication method of liquid crystal devices (LCD). Single-wall carbon nanotubes (SWNTs) are deposited onto a substrate via layer-by-layer (LBL) process. This SWNT LBL electrode is an appealing replacement of conventional indium tin oxide (ITO) transparent electrode for its superior optoelectronic performance. Vertically aligned LCD cells with the new electrode exhibited a voltage-transmittance curve similar to that of the conventional ITO electrode, and the enhanced display performance with the number of SWNT layers. Tang et al. [2] investigated the film growth characteristics and anti-coking performance of CVD (chemical vapor deposition)-based $\mathrm{TiN}$ and $\mathrm{TiO}_{2}$ anti-coking coatings. Coating growth characteristics are importantly dependent on deposition time, residence time, and partial pressure. Coking tests showed that both $\mathrm{TiN}$ and $\mathrm{TiO}_{2}$ coatings satisfactorily inhibited catalytic coking. Li et al. [3] compared the performances of ultrafine powder coatings with two different fillers $\left(\mathrm{Al}(\mathrm{OH})_{3}\right.$ and $\left.\mathrm{BaSO}_{4}\right)$. Powder coatings consist of polymer resins, fillers, curing agents, additives, and pigments. Unlike $\mathrm{BaSO}_{4}$ filler, $\mathrm{Al}(\mathrm{OH})_{3}$ filler contains the polar groups (hydrogen bond), which induces the chain formation between inorganic filler and organic polymer resin. Several tests were conducted to measure extensive mechanical properties of the films, and films with $\mathrm{Al}(\mathrm{OH})_{3}$ fillers were found to be better in mechanical properties and durability aspects. Algahtani et al. [4] conducted a series of experiments to determine the most efficient deposition method for the ceramic surface coating with good anti-corrosion ability. SEM and optical microscope were used to observe microstructures of the coated films, and corrosion performance of the films was tested via several electrochemical experiments including inductive coupled plasma (ICP) test. Nguyen et al. [5] designed mathematical models for the drying of lemongrass using the convection drying device. Mass of lemongrass was measured under different drying conditions to calculate the moisture content, and moisture diffusivity and activation energy of the drying process were nicely fitted from raw data. Kern et al. [6] suggested an alternative approach for developing paint and coating products. The digital platform to stably suggest the new formulation of paints from reliable data was ingeniously established. In this experiment, the digital platform effectively reduced the non-value-added activities and also the total throughput time. Gathering reliable safety and/or price data and formulating them into the structured form are crucial in this method. Khan et al. $[7,8]$ and Ullah et al. [9] focused on the thin film flows on time-dependent stretching surface under the presence of the magnetic field. This magnetohydrodynamics (MHD) issue was scrutinized both numerically and analytically, giving good agreement with each other. The analytical results were acquired employing the homotopy analysis method (HAM).

Conflicts of Interest: The author declares no conflict of interest. 


\section{References}

1. Moon, G.; Jang, W.; Son, I.; Cho, H.; Park, Y.; Lee, J. Fabrication of New Liquid Crystal Device Using Layer-by-Layer Thin Film Process. Processes 2018, 6, 108. [CrossRef]

2. Tang, S.; Liu, T.; Duan, S.; Guo, J.; Tang, A. Comparison of Growth Characteristics and Properties of CVD $\mathrm{TiN}$ and $\mathrm{TiO}_{2}$ Anti-Coking Coatings. Processes 2019, 7, 574. [CrossRef]

3. Li, W.; Franco, D.; Yang, M.; Zhu, X.; Zhang, H.; Shao, Y.; Zhang, H.; Zhu, J. Comparative Study of the Performances of $\mathrm{Al}(\mathrm{OH})_{3}$ and $\mathrm{BaSO}_{4}$ in Ultrafine Powder Coatings. Processes 2019, 7, 316. [CrossRef]

4. Algahtani, A.; Mahmoud, E.; Khan, S.; Tirth, V. Experimental Studies on Corrosion Behavior of Ceramic Surface Coating using Different Deposition Techniques on 6082-T6 Aluminum Alloy. Processes 2018, 6, 240. [CrossRef]

5. Nguyen, T.; Nguyen, M.; Nguyen, D.; Bach, L.; Lam, T. Model for Thin Layer Drying of Lemongrass (Cymbopogon citratus) by Hot Air. Processes 2019, 7, 21. [CrossRef]

6. Kern, T.; Krhač, E.; Senegačnik, M.; Urh, B. Digitalizing the Paints and Coatings Development Process. Processes 2019, 7, 539. [CrossRef]

7. Khan, A.; Nie, Y.; Shah, Z. Impact of Thermal Radiation and Heat Source/Sink on MHD Time-Dependent Thin-Film Flow of Oldroyed-B, Maxwell, and Jeffry Fluids over a Stretching Surface. Processes 2019, 7, 191. [CrossRef]

8. Khan, A.; Nie, Y.; Shah, Z. Impact of Thermal Radiation on Magnetohydrodynamic Unsteady Thin Film Flow of Sisko Fluid over a Stretching Surface. Processes 2019, 7, 369. [CrossRef]

9. Ullah, A.; Shah, Z.; Kumam, P.; Ayaz, M.; Islam, S.; Jameel, M. Viscoelastic MHD Nanofluid Thin Film Flow over an Unsteady Vertical Stretching Sheet with Entropy Generation. Processes 2019, 7, 262. [CrossRef]

(C) 2020 by the author. Licensee MDPI, Basel, Switzerland. This article is an open access article distributed under the terms and conditions of the Creative Commons Attribution (CC BY) license (http://creativecommons.org/licenses/by/4.0/). 